\title{
Influence of capital structure on profitability: Empirical Evidence from listed Nigerian banks
}

\author{
${ }^{1}$ Idode, Patrick Esiemogie, ${ }^{2}$ Adeleke, Toyin Mary, ${ }^{3}$ Ogunlowore, Akindele John, \\ ${ }^{4}$ Ashogbon, Oyekan Samuel \\ ${ }^{1}$ Department of Economics, Accounting and Finance Bells University of Technology, Ota, Ogun State, Nigeria \\ ${ }^{2}$ Department of Accountancy Federal Polytechnic Ado Ekiti, Ekiti State, Nigeria \\ ${ }^{3}$ Department of Economics, Accounting and Finance Bells University of Technology, Ota, Ogun State, Nigeria \\ ${ }^{4}$ Department of Accounting Education, School of Business Education, Federal College of Education (Technical) \\ Akoka, Lagos
}

\begin{abstract}
This study examines the influence of capital structure on profitability of listed Nigerian banks and data was obtained of listed banks on the Nigeria Stock Exchange (NSE) from 2008 to 2012 covering a period of five years. For this study, expofactor descriptive research design was adopted and multiple regression technique was applied. The dependant variable for the study is Return on Assets (ROA) measured as Earnings before tax (EBT) divided by total assets. The independent variables are total debts to total assets ratio (LEVI) and equity to total assets (LEVII).

The findings of this study show that capital structure has a significant positive influence on the profitability of Nigerian banks during the period of study. Therefore, it was recommended that Directors and management should use both equity and debt in financing the business because there is a significant positive relationship between capital structure and profitability of listed banks in Nigeria. Management should endeavour to finance their activities with equity and debts as supported by the pecking order theory and agency theory.
\end{abstract}

Keywords: Total Debt, Equity, Total Asset, Profitability.

\section{Introduction}

Capital structure is the mix of debt and equity that a company uses to finance its business. Hence, the relationship between capital structure and firm value has been extensively investigated in the past few decades. (Damodaran, 2001) Modigliani and Miller (1958) suggested that, in a world without friction, there is no difference between debt and equity financing as regards the value of the firms. Thus, financing decision adds no value and are therefore of no concern to managers. Capital structure is one of the important financial decisions for any business organization. This decision is important because the organization needs to maximize returns to various organizations and also have an effect on the value of the firm. (Ahmad, 2012)

Besides that, the impact from the decision will help the firm's ability to deal with its competitive environment. Furthermore, the capital structure of a firm is a mix of debt and equity that is used by a firm to enhance its operation. Thus, a firm's specific strategy should deal with the appropriate mix of debt and equity to finance the firm's assets.

Capital structure decisions represent another important financial decision of a business organization apart from investment decisions. It is important since it involves a huge amount of money and has long- term implications on the firms. (Ahmad 2012). Though Miller and Modigliani (1958) have theoretically argued and proved that capital structure is irrelevant in a perfect market condition, characterized by the capital market with no taxes, no transaction costs and homogenous expectations, other works that assume several market imperfections on the contrary suggest that capital structure decisions are relevant since it can affect shareholders' wealth. Modigliani and Miller (1963) in considering the existence of corporate taxes suggested that firms should use as much debt capital as possible in order to maximize their value by maximizing the interest tax shield.

Other theories that have been advanced to explain the capital structure of firms include the pecking order theory, static trade-off theory, and the agency cost theory. Pecking order theory suggests that firms will initially rely on internally generated funds, and then they will turn to debt if additional funds are needed and finally they will issue equity to cover any remaining.

Due to the lack of a consensus about what would qualify as optimal capital structure, it is pertinent to examine the effect of debt utilization on firms' performance. Several such studies were conducted; they found contradictory results when Gleason (2000) supported a negative impact of leverage on the profitability of the firm while Roden and Lewellen (1995) found a significant positive association between profitability and total 
debt as a percentage of the total buyout-financing package in their study on leveraged buyouts. Thus, there is no universal theory about debt-equity choices and there are different views regarding the financing option.

The relationship between capital structure and profitability is one that received considerable attention in the finance literature. Nonetheless, in the context of the banking industry, the subject has received a limited research attention.

The banking sector in most economics is so critical that it attracts much attention from the domestic financial institutions, governmental regulatory authorities and international institutions.

The study regarding the effects of capital structure on profitability will help us to know the potential problems in performance and capital structure. The modern banks must conduct their business in a highly complex and competitive business environment (Niresh \& Velnampy 2012). Therefore; these types of research findings will be benefited in selecting the capital structure to achieve the optimum level of banks' profitability. The purpose of conducting this study is to assess the influence of capital structure on banking performance using profitability as measurement to provide empirical evidence regarding Nigerian banking sector over a period of five years from 2008 to 2012 .

\section{Statement Of Problem}

An appropriate capital structure is a critical decision for any business organization. The decision is important not only because of the need to maximize returns to various organizational constituencies, but also because of the impact such a decision will have on an organization's ability to deal with its competitive environment (David 2010). The relationship between capital structure and profitability is one that received considerable attention in the finance literature. Nonetheless, in the context of the banking industry, the subject has received a limited research attention. The difficulty facing firms in Nigeria has to do more with the financing - whether to raise debt or equity capital. The issue of finance is so important that it has been identified as an immediate reason for business failing to start in the first place or to progress (Graham ,1996). Thus it is necessary for listed banks in Nigeria to be able to finance their activities and grow over time, if they are ever to play an increasing and predominant role in creating value added, as well as income in terms of profits. From the foregoing, it is therefore important to understand how banks' financing choice affects their performance The difficulties associated with designing optimum capital structure policies to enhance profitability is the reason why this study sought to assess whether capital structure influence banks' performance concentrating on the fifteen (15) selected banks.

\section{Objective Of The Study}

The objectives of this study include:

1. To observe the influence of total debt ratio on the profitability of listed Nigerian banks.

2. To examine the effect of equity ratio on the profitability of listed Nigerian banks.

\section{Research Questions}

The following research questions guided this study:

1) To what extent does total debt influence profitability of listed Nigerian banks?

2) To what degree is the profitability of listed Nigerian banks influenced by equity?

\section{The Concept Of Capital Structure}

\section{Literature Review}

One of the most important reference theories in enterprises financing policy is the capital structure. The capital structure is the mix of different types of securities including debt, preference stock and equity issued by a company to finance its assets; this is referred to as the firm's long term financial mix. (Watson and Head, 2007). In finance, capital structure refers to the way a corporation finances its assets, through some combination of equity, debt or hybrid securities (Saad, 2010). In other words, it means the financing of a firm's operation by owners and others that lay claims on the assets of the firm profitability reflects the outcome of all capital structure decision; debt equity choice which inputs are converted to outputs in corporate organization capital structure, otherwise referred to as financial structure, is the means by which an organization is financed.

\section{Review Of Empirical Studies}

The literature on the relationship between firm performance and capital structure has produced mixed results.

A study has been done by Nimalathasan \& Brabete (2010) pointed out capital structure and its impact on profitability: a study of listed companies in Sri Lanka. The analysis shows that debt-equity ratio is positively and strongly associated to all profitability ratios (Gross profit, operating profit and net profit ratios). While, in Ghana Abor (2005) posited that the influence of capital structure profitability of listed companies on the Ghana stock 
exchange during a five-year period, shows that there is significant positive interrelation between short-term debt to asset ratio (SDA) and ROE and shows that firms which earn a lot use more short-term debt to finance their business, which represents 85 percent of total debt financing. Yet, the results showed the adverse relation between long-term debt to asset ratio (LDA) and ROE. Arbiyan \& Safari (2009) investigate the effect of capital structure on profitability using 100 Iranian listed firms from 2001 to 2007. They found short-term and total debts are positively related to profitability (ROE, which indicate a negative relation between long-term debts and ROE). Haung \& Song (2006) found a negative correlation between leverage and performance (earnings before interest and tax to total asset in china firms. In another study of same though,

In another study of Ehaid (2009), capital structure has weak-to-on influence on the financial performance of listed firms in Egypt. By using three accounting based measurement of financial performance which are return on asset (ROA), return on equity (ROE) and gross margin (GM), the empirical tests come out with the result that capital structure (particularly short-term debt and total debt) which is measured by return on asset (ROA) have a negative impact on an organization's performance. Apart from that, capital structure (including short-term debt, long term debt and total debt) which is measured by return on equity (ROE) and gross margin (GM) have no significant impact on an organization's performance.

Zeitun \& Tian (2007) find out that firm's capital structure have a significant and negative impact on the firm's performance measures in both the accounting and market measures. Base on the variables in a capital structure, Zeitun \& Tian (2007) indicated that there are many variables in a capital structure choice and structure of debt maturity which will affect a company's performance.

Amidu (2007) conducted a study to investigate the dynamics involved in the determination of the capital structure of the Ghana banks. The dependent variables used in this paper are the leverage (LEV) is total debts divided by total capital; short-term debt ratio (SHORT) is total short-term debt to capital while long-term debt ratio (LONG) is the total long-term debt divided by total capital. The explanatory variables include (PRE) profitability, (RSK) risk, and asset structure (AST), tax (TAX), size (SZE) and sales growth (GROW). The regression line model is use in this research and the result was a negative relationship between profitability and leverage. The results of prior studies show that higher profits increase the level of internal financing (Titman and Wessels 1988).Profitable banks accumulate internal reserves and this enables them to depend less on external funds. The results of this study show that profitability, corporate tax, growth, asset structure and bank size influence bank's financing or capital structure decision. The significant finding of this study is that more than 87 percent of the banks, assets are financed by debts and out of this short- term debt appear to constitute more than three quarters of the capital of the banks. This highlights the importance of short-term debts over long-term debts in Ghanaian banks financing. Pratheepkanth (2011) conducted a study his finding regarding the capital structure (CS) and its impact on financial performance during 2005 to 2009 of business organizations in Sri Lanka. The result of research validated a negative relationship between capital structure (CS) and financial performances of the Sri Lankan companies. Ibrahim (2009) examined the impact of capital structure choice on firm performance in Egypt, using a multiple regression analysis in estimating the relationship between leverage level and firm's performance, the study cover between 1997 and 2005. Three accounting based measures of financial performance (return on Equity, return on Assets and gross profit margin) were used. The result revealed that capital structure choice decision in general, has a weak-to-no impact on firm's performance.

Madan (2007) examined the role of financing decision in the overall performance of companies. The study concluded that while leverage seems to be working well for few categories of companies, it is affecting some others negatively. Thus, firms that have been moderately geared have been able to generate a good return on equity. Companies that are moderately geared, in the range of gearing ratio of 50 percent until 85 percent, have been able to generate a good ROE. Hence, low-geared companies and very highly geared companies need to work on improving their ROE by either increasing or reducing their debt-equity mix respectively. Supporting by Zeitun and Tian (2007), a firm's capital structure was found to have a significant on the firm's performance measures in both accounting, ROA and ROE.

\section{Research Methodology}

The main purpose of this research is to establish whether or not there exists any relationship between capital structure and bank profitability. For this study, expofactor descriptive research design was used. The choice of this research approach is based on the advantages and reliability of results associated with it. It suffices to say that the descriptive research emphasize accurate measurement of phenomena and require unbiased and reliable observations.

The population consists of all the twenty one (21) quoted banks on the Nigerian stock exchange from 2008 to 2012. The sample of the study comprises of only fifteen (15) banks and the banks must be operation from 2008 to 2012. The major sources of data collection for this study are through the secondary sources extracted from annual reports of the sampled banks as contained in Nigeria stock exchange fact book. 
The data were analyzed using multiple regression technique and results presented in form of tables, with textual narrations.

\section{Definition Of Variables}

This study involves three (3) variables namely:- profitability as a dependent variable and total debt ratio and equity ratio as independent variables. The variables are describe below

1. Profitability (PROF): The Return on Equity (ROE) is used in this study as a measure of profitability and is defined as Earnings before Tax (EBT) divided by total assets of the firm This measure is referred to the others because it measures the overall efficiency of the firm in generating returns for its shareholders

2. Equity Ratio:-is a financial ratio indicating the relative proportion of equity used to finance a company's assets. It measures the proportion of the total assets that are financed by stockholders and not creditors. A low equity ratio will produce good results for stockholders as long as the company earns a rate of return on assets that is greater than the interest rate paid to creditors.

3. Total Debt Ratio: Total debt ratio is use frequently in the financial world. This term is often used when applying for a mortgage or loan, or for filing for bankruptcy. In either example the total debt ratio will be the same even though it is being used for two totally different purposes. It is use to determine how much indebtedness you are carrying and what kind of financial risk you are. This gives a lender or bankruptcy court an idea of where you stand in your finances. Theoretically, this number will show whether you are at financial risk or in good financial standing.

\section{Specification Of Model}

This study adopted a model used by Oke and Afolabi (2010) with little modification to suit this study. The model for this study is as follows:-

$\mathrm{ROA}=\mathrm{F}(\mathrm{CS})$

$\mathrm{CS}=(\mathrm{DR}, \mathrm{EQT})$

$\mathrm{ROA}=\mathrm{f}(\mathrm{DR}, \mathrm{EQT})$

Prof $=\mathrm{ROA}$

$\mathrm{ROA}=\beta 0+\beta 1 \mathrm{DR}+\beta 2 \mathrm{EQT}+\mathrm{ei}$

Where:

Prof $=$ profitability

ROA = Return On Asset

$\mathrm{DR}=$ Debt ratio over the period

$\mathrm{EQT}=$ Equity ratio over the period

$\mathrm{Bo}=$ Constant

B1 -B2 = Coefficient

$\mathrm{CS}=$ Capital structure

ei $=$ error term, representing factors other than those specified in the model

\section{Results And Findings}

This section presents, analysed and interpreted data collected for this study.

Table1: Descriptive statistics using SPSS

Descriptive Statistics

\begin{tabular}{|l|r|r|r|r|r|}
\hline & \multicolumn{1}{|c|}{$\mathrm{N}$} & \multicolumn{1}{|c|}{ Minimum } & Maximum & \multicolumn{1}{c|}{ Mean } & Std. Dev iation \\
\hline ROA & 15 & .01 & .09 & .0240 & .02131 \\
LEV1 & 15 & .76 & 1.10 & .8640 & .08016 \\
LEV2 & 15 & .09 & .23 & .1567 & .04370 \\
Valid N (listwise) & 15 & & & & \\
\hline
\end{tabular}

\section{Source: Authors' computation (2014)}

Table 1 above presents the descriptive statistics of the dependents and independent variables. The mean, value of Return on Assets (ROA) of Nigerian banks during the research period amounted to 2.4 percent. This is to say Nigerian banks' ROA during the study period is four (2) percent. It also reviews the poor performance of profitability of sampled Banks over the study period. LEVI (measured as total debts divided by total assets) is 86.4 percent. This result shows that only 13.6 percent of Nigerian banks capital is financed by source other than debts during the study period. LEVII (measured by total shareholders' equity divided by total assets) averaged 15.67 percent over the study period. It also reveals that, of the 84.3 percent total debts ratio of Nigerian banks. 
Return on Assets (ROA) of Nigerian banks during the period of study is a minimum of 0.1 while the maximum is 0.9 percent. This result shows that some bank managers have not been utilizing effectively the assets of the owners entrusted to them. Total debts to total assets ratio (LevI) of Nigerian Banks had the minimum value of 76 percent and the maximum value of 110 percent while total shareholder's equity to total assets ratio (LEVII) had a minimum value of 9 percent and a maximum value of 23 percent during the study period. This result indicates that some Nigerian banks had debts over their total assets during the study.

\section{Regression analysis}

Table 2

Dependent Variable: ROA

Method: Least Squares

Date: 05/24/14 Time: 23:16

Sample: 115

Included observations: 15

\begin{tabular}{lrrrr}
\hline \multicolumn{1}{c}{ Variable } & Coefficient & Std. Error & t-Statistic & Prob. \\
\hline LEV1 & -0.219057 & 0.052341 & -4.185211 & 0.0013 \\
LEV2 & 0.245852 & 0.050607 & 4.858069 & 0.0004 \\
& 0.195575 & 0.092834 & 2.106704 & 0.0569 \\
\hline \hline R-squared & 0.663425 & Mean dependent var & \\
Adjusted R-squared & 0.607329 & S.D. dependent var & 0.024000 \\
S.E. of regression & 0.013356 Akaike info criterion & \\
Sum squared resid & 0.002141 & Schwarz criterion & -5.61314 \\
Log likelihood & 45.12626 & F-statistic & -5.475224 \\
Durbin-Watson stat & 2.295404 Prob(F-statistic) & & 11.82663 \\
\hline
\end{tabular}

Source: Authors' computation (2014)

Table 2 above presents the summary of regression results of model 1. In this table, Return on assets (which is measured by Earnings before Tax (EBT) divided by total assets of the firm) was regressed against two independent variables: Levi \& Levi. This produced a coefficient of determination (R2) of 61 percent. This is to say the identified variables in the model account for 61 percent in the variability of Return on assets while the remaining 39 percent is accounted for by other variables not included in the model which shows that there exist goodness of fit. The F-statistics (11.82) is statistically significant at 5\% level of significant which shows that the model is well specified. Durbin- Watson (DW) of 2.2 shows the absence of non auto-correlation which shows that the model specified is free from the problem of serial auto-correlation.

\section{Discussion Of Findings}

This section discussed the finding of the study on influence of capital structure on the profitability of listed Nigerian banks:

The impact of LEVI on ROA: The result of the regression analysis indicates that total debts ratio (LEVI) is positively signed and statistically significant at $5 \%$ level of significant. The result indicated that a unit change in total debt ratio (LEVI) will lead to $25 \%$ increases in Return on asset (ROA). this result is corresponding with the findings of Ahmad, Abdullah and Roslan (2012) which stated that total debt has a significant positive influence on return on asset of selected firms. This result show that capital structure has a significant positive influence on the profitability of Nigerian banks during the period of study

The impact of LEVII on ROA: The result of regression analysis presented in table 2 also shows that LEVII is positively signed and statistically significant at $5 \%$ level of significant. This result indicated that a unit change in equity ratio (LEVII) will lead to $20 \%$ increase in return on assets (ROA), this result show that capital structure has significant positive influence on the performance of Nigerian banks during the period of study. This result is corresponding with findings of Zeitun and Tian (2007)

From this finding, it was discovered that there is a significant effect of capital structure on Banks profitability. It means that decisions on capital structure taken by the banks affect the profitability of the banks.

\section{Conclusions}

The following are the conclusions of this study. The major objective of capital structure is to have an adequate mix of debt and equity that can maximize the shareholders wealth (Watson \& Head,2007), but regrettably, this objective is not always feasible as a result of some observed deficiencies like management inefficiency, inherent business risk, declining ethics and gross insider abuse. This study finds out that profitability is negatively related to capital structure and statistically not significant with short term debts to total assets and total debts. 


\section{Recommendations}

Management should be careful while using debt as a source of finance since a negative relationship exists between the capital structure and performance variables used in this study. They should seek to finance their activities with retained earnings and use debts as a last option as supported by the pecking order theory.

\section{References}

[1]. Abor, O. (2005). 'The Effect of Capital Structure on Profitability: An Empirical Analysis of Listed Firms in Ghana.' Journal of Risk Finance, 6(5), 438-445.

[2]. Ahmad, Z (2012),'capital structure effect on firms' performance: focusing on consumers and industrials sectors on Malaysian firms". International review of business research papers, vol. 8 pp. 137-155

[3]. Amidu, M. (2007). Determinants of capital structure of banks in Ghana: an empirical approach. Baltic Journal of Management, 2(1), 67-79.

[4]. Arbabiyan, A and Safari, M (2009). "The effects of capital structure and profitability in the listed firms in Tehran Stock Exchange", Journal of Management Perspective, 33:159-175.

[5]. Damodaran, A (2001), Corporate Finance: Theory and Practice, 2nd edn, Wiley

[6]. David, D and Olorunfemi, S (2010), "Capital structure and corporate performance in Nigeria petroleum industry: panel data analysis", Journal of mathematics and statistics vol. 6(2) pp $168-173$

[7]. Ehaid, I.E. (2009). The Impact of Capital Structure Choice on Firm's Performance: Empirical Evidence from Egypt. Journal of Risk Finance, Vol.7, Pp77- 487.

[8]. Gleason, K, Mathur, L and Mathur I (2000), 'The interrelationship between cultures capital structure, and performance: Evidence from European retailers', Journals of Business Research, vol.50, pp.185-91

[9]. Graham, J.R.,( 1996). Debt and the marginal tax rate. J. Financial Econ., 41: 41-74.

[10]. Haugh, G. and Song, F.M. (2006). The Determinant of Capital Structure: Evidence from China. China Economic Review, 17, 1436.

[11]. Ibrahim, E. (2009). "The Impact of Capita-structure choice on firm Performance: Empirical evidence from Egypt." The Journal of Risk Finance, vol. 10, No.5, pp 477-487

[12]. Madan, K. (2007), 'An analysis of the debt-equity structures of leading hotel chains in India', International Journal of Contemporary Hospitality Management, vol.19 no.5, pp.397-414.

[13]. Modigliani, F. and Miller, M. (1963). Corporation Income Tax and the Cost of Capital. A Correction, American Economic Review, 48, 433 - 443

[14]. Modiguani, F. and Miller, M. (1958). The Cost of Capital, Corporation Finance and the Theory of Investment. The American Economic Review, 48(3), 261-297.

[15]. Nimalathasan, B., \& Brabete, V. (2010) Capital Structure and Its Impact on Profitability: A Study of Listed Manufacturing Companies in Sri Lanka (2010), Revista Tinerilor Economisti/The Young Economists Journal 13,55-61

[16]. Niresh, J \& Velnampy, T (2012, "The Relationship between Capital Structure \& Profitability", Global Journal of Management and Business Research, vol.12

[17]. Nsude, F.I. (2005). Fundamentals of Statistics for Business (2nd ed.). Enugu: CIDJAP Printing Press.

[18]. Oke, O. \& Afolabi, B. (2010). Capital Structure and Industrial Performance in Nigeria. International Business and Management Vol. 2, No. 1. 2011, pp. 100-106 Olowe, R.A., 1998. Financial Management; Concepts, Analysis and Capital Investments. 1st Edn., Brierly Jones Nigeria Ltd, Lagos, pp: 361-391.

[19]. Puwanenthiren P, (2011). "Capital Structure and Financial Performance: Evidence from Selected Business Companies in Colombo Stock Exchange Sri Roden, M and Lewellen, G (1995), 'Corporate capital structure decisions: evidence from leveraged buyouts,' Financial Management, vol. 24, pp. 76-87.

[20]. Saad, M. (2010). Corporate Governance, Compliance and the Effects to Capital Structure International. Journal of Financial Economics, 2(1), 105-114.

[21]. Titman, S., \& Wessels, R. (1988). The determinants of capital structure choice.Journal of Finance, 43(1), 1-19.

[22]. Watson, D. and Head, A. (2007).Corporate Finance Principal and Practice, 4/E. Financial Time Press. Pp 528

[23]. Zeitun, R. and Tain, G. (2007). Capital Structure and Corporate Performance: Evidence from Jordan. Australisian Accounting Business and Finance Journal, 1(4).

\section{Appendix 1}

Summary Value Of Dependent And Independentvariables

\begin{tabular}{|l|l|l|}
\hline LEV1 & LEV2 & ROA \\
\hline 0.83 & 0.15 & 0.01 \\
\hline 1.1 & 0.16 & 0.09 \\
\hline 0.82 & 0.22 & 0.02 \\
\hline 0.9 & 0.12 & 0.01 \\
\hline 0.82 & 0.17 & 0.04 \\
\hline 0.91 & 0.16 & 0.03 \\
\hline 0.9 & 0.12 & 0.01 \\
\hline 0.81 & 0.19 & 0.03 \\
\hline 0.85 & 0.15 & 0.01 \\
\hline 0.88 & 0.12 & 0.01 \\
\hline 0.76 & 0.23 & 0.01 \\
\hline 0.82 & 0.17 & 0.02 \\
\hline 0.78 & 0.21 & 0.01 \\
\hline 0.89 & 0.09 & 0.02 \\
\hline 0.89 & 0.09 & 0.04 \\
\hline
\end{tabular}


Appendix 2 The Names Of Sampled Banks

\begin{tabular}{|l|l|l|l|}
\hline S/N & Names of banks & S/N & Names of banks \\
\hline 1 & First bank of Nigeria & 9 & Diamond bank \\
\hline 2 & Union bank of Nigeria & 10 & Fidelity bank \\
\hline 3 & Zenith bank of Nigeria & 11 & UBA bank \\
\hline 4 & Wema bank of Nigeria & 12 & Stanbic ibtc \\
\hline 5 & Access bank of Nigeria & 13 & Fcmb \\
\hline 6 & Guaranty trust bank of Nigeria & 14 & Sterling bank \\
\hline 7 & Eco bank of Nigeria & 15 & Unity bank \\
\hline 8 & Skye bank & & \\
\hline
\end{tabular}

Appendix 3 Levi=Total Debts/Total Assets

\begin{tabular}{|l|l|l|l|l|l|l|l|}
\hline $\mathbf{S} / \mathbf{N}$ & & $\mathbf{2 0 0 8}$ & $\mathbf{2 0 0 9}$ & $\mathbf{2 0 1 0}$ & $\mathbf{2 0 1 1}$ & $\mathbf{2 0 1 2}$ & Average \\
\hline 1 & Names of banks & 0.81 & 0.82 & 0.79 & 0.88 & 0.89 & 0.83 \\
\hline 2 & Diamond bank & 1.25 & 1.40 & 0.95 & 0.97 & 0.99 & 1.1 \\
\hline 3 & Wema bank & 0.83 & 0.76 & 0.79 & 0.88 & 0.86 & 0.82 \\
\hline 4 & Access bank & 0.88 & 0.86 & 0.99 & 0.88 & 0.89 & 0.9 \\
\hline 5 & Skye bank & 0.81 & 0.82 & 0.81 & 0.85 & 0.83 & 0.82 \\
\hline 6 & Gtb bank & 0.95 & 0.97 & 0.86 & 0.88 & 0.87 & 0.91 \\
\hline 7 & Union bank & 0.88 & 0.88 & 0.90 & 0.92 & 0.92 & 0.9 \\
\hline 8 & UBA bank & 0.80 & 0.79 & 0.80 & 0.83 & 0.82 & 0.81 \\
\hline 9 & Zenith bank & 0.83 & 0.85 & 0.85 & 0.86 & 0.86 & 0.85 \\
\hline 10 & First bank & 0.85 & 0.83 & 0.88 & 0.9 & 0.96 & 0.88 \\
\hline 11 & Eco bank & 0.80 & 0.77 & 0.72 & 0.72 & 0.81 & 0.76 \\
\hline 12 & Fidelity bank & 0.78 & 0.77 & 0.79 & 0.87 & 0.90 & 0.82 \\
\hline 13 & Stanbic bank & 0.74 & 0.72 & 0.79 & 0.80 & 0.87 & 0.78 \\
\hline 15 & Fcmb bank & 0.88 & 0.89 & 0.90 & 0.91 & 0.91 & 0.89 \\
\hline
\end{tabular}

Appendix 4 Levii=Total Shareholders Equity/Total Assets

\begin{tabular}{|l|l|l|l|l|l|l|l|}
\hline & & & & & \\
$\mathbf{S} / \mathbf{N}$ & Names of banks & $\mathbf{2 0 0 8}$ & $\mathbf{2 0 0 9}$ & $\mathbf{2 0 1 0}$ & $\mathbf{2 0 1 1}$ & $\mathbf{2 0 1 2}$ & Average \\
\hline 1 & Diamond bank & 0.18 & 0.18 & 0.19 & 0.12 & 0.10 & 0.15 \\
\hline 2 & Wema bank & 0.20 & 0.17 & 0.16 & 0.14 & 0.13 & 0.16 \\
\hline 3 & Access bank & 0.25 & 0.30 & 0.26 & 0.13 & 0.16 & 0.22 \\
\hline 4 & Skye bank & 0.15 & 0.11 & 0.10 & 0.15 & 0.11 & 0.12 \\
\hline 5 & Gtb bank & 0.19 & 0.18 & 0.19 & 0.14 & 0.16 & 0.17 \\
\hline 6 & Union bank & 0.12 & 0.05 & 0.24 & 0.20 & 0.18 & 0.16 \\
\hline 7 & UBA bank & 0.12 & 0.13 & 0.13 & 0.11 & 0.11 & 0.12 \\
\hline 8 & Zenith bank & 0.20 & 0.21 & 0.20 & 0.17 & 0.18 & 0.19 \\
\hline 9 & First bank & 0.17 & 0.15 & 0.17 & 0.13 & 0.14 & 0.15 \\
\hline 10 & Eco bank & 0.14 & 0.14 & 0.12 & 0.09 & 0.11 & 0.12 \\
\hline 11 & Fidelity bank & 0.26 & 0.30 & 0.26 & 0.18 & 0.16 & 0.23 \\
\hline 12 & Stanbic bank & 0.25 & 0.26 & 0.21 & 0.13 & 0.09 & 0.17 \\
\hline 13 & Fcmb bank & 0.25 & 0.26 & 0.21 & 0.19 & 0.13 & 0.21 \\
\hline 14 & Sterling bank & 0.10 & 0.11 & 0.10 & 0.08 & 0.08 & 0.09 \\
\hline 15 & Unity bank & 0.05 & 0.03 & 0.14 & 0.12 & 0.13 & 0.09 \\
\hline
\end{tabular}

APPENDIX 5

RETURNON ASSETS (ROA) $=$ EBT/TOTAL ASSETS

\begin{tabular}{|l|l|l|l|l|l|l|l|}
\hline $\mathbf{S} / \mathbf{N}$ & Names of banks & $\mathbf{2 0 0 8}$ & $\mathbf{2 0 0 9}$ & $\mathbf{2 0 1 0}$ & $\mathbf{2 0 1 1}$ & $\mathbf{2 0 1 2}$ & Average \\
\hline 1 & Diamond bank & 0.00 & 0.29 & 0.00 & 0.02 & 0.02 & 0.01 \\
\hline 2 & Wema bank & 0.18 & 0.02 & 0.07 & 0.17 & 0.02 & 0.09 \\
\hline 3 & Access bank & 0.03 & 0.00 & 0.02 & 0.02 & 0.03 & 0.02 \\
\hline 4 & Skye bank & 0.03 & 0.00 & 0.02 & 0.00 & 0.01 & 0.01 \\
\hline 5 & Gtb bank & 0.04 & 0.03 & 0.04 & 0.04 & 0.06 & 0.04 \\
\hline 6 & Union bank & 0.03 & 0.06 & 0.02 & 0.02 & 0.02 & 0.03 \\
\hline 7 & UBA bank & 0.03 & 0.01 & 0.00 & 0.01 & 0.02 & 0.01 \\
\hline 8 & Zenith bank & 0.03 & 0.03 & 0.03 & 0.03 & 0.04 & 0.03 \\
\hline 9 & First bank & 0.01 & 0.01 & 0.01 & 0.01 & 0.03 & 0.01 \\
\hline 10 & Eco bank & 0.00 & 0.02 & 0.00 & 0.02 & 0.00 & 0.01 \\
\hline 11 & Fidelity bank & 0.01 & 0.00 & 0.02 & 0.00 & 0.02 & 0.01 \\
\hline 12 & Stanbic bank & 0.03 & 0.02 & 0.03 & 0.02 & 0.01 & 0.02 \\
\hline 13 & Fcmb bank & 0.01 & 0.00 & 0.01 & 0.02 & 0.01 & 0.01 \\
\hline 14 & Sterling bank & 0.02 & 0.04 & 0.01 & 0.01 & 0.01 & 0.02 \\
\hline 15 & Unity bank & 0.06 & 0.08 & 0.04 & 0.01 & 0.02 & 0.04 \\
\hline
\end{tabular}

